\title{
Row over government support for West German universities
}

\section{Munich}

A Row over the level of government support for university research in West Germany has broken out between the university rectors' association (Westdeutschen Rektorenkonferenz) and the research ministry.

At the association's annual meeting in Göttingen last week, the outgoing president, Theodor Berchem, appealed for more government support. He protested that the university research budget, estimated at DM 59,300 for 1987, is less than one-seventh of the funds currently spent on research by industry and government.

Research Minister Heinz Riesenhuber was quick to reply. He said that the biggest problem is quality, not quantity: "the money is there, but (good) people to use it are in short supply".

Riesenhuber's snappy reply provides a clue to several serious difficulties confronting West German university researchers, although few would agree that quantity is any less of a problem than quality. Universities have been filled far beyond capacity for at least ten years, reducing the amount of time professors can devote to their research. According to one rector, Gisbert Freiherr zu Putlitz at the University of Heidelberg, almost a whole generation of professors has done little more than teach, to the point where they are hardly capable of redirecting their efforts to research.

New academic positions are in short supply. Of every 1,000 people who achieve the level of Habilitation, a pre-professorial post reached by the best young researchers, only seven have a chance at tenure-track positions.

The situation in West Germany is complicated by the large number of sources of funding for the universities. It is the responsibility of the Federal Ministry of Education (BMBW) to provide what federal support there is for the universities, which are also funded in part by the states. The Research Ministry (BMFT) provides funds for applied research in universities and Hochschulen as well as for space and nuclear research and other large-scale programmes. Grants for basic research issue from the Deutsche Forschungsgemeinschaft (DFG). All of these bodies, as well as state governments and industry, will have to play a role if the pressure on West German universities is to be relieved.

Maintaining the current level of quality in research would not be too hard, said zu Putlitz, as long as more money became available. "DM4 million would make a very big difference", he said.

Sometimes experiments cannot be per- formed simply because there is not enough money for the electricity bill. The $2-3$ per cent yearly increase in university budgets just barely covers personne costs, said zu Putlitz. Furthermore, the university budgets are not as high as they look, since included in them are mandatory 5 per cent reductions which must not be spent by the universities.

To improve university research, rather than just maintain its level, more would have to be done. Zu Putlitz stressed the need to reduce the student-faculty ratio and hire young professors who are more research-orientated than previously.
Even if working conditions for researchers are improved, it does not mean that the best people will stay in West Germany for postdoctoral or junior faculty positions. The Heisenberg Fellows programme, supported by the DFG, and the Fiebiger Program both attempt to hang onto these young researchers for a few years until more tenure-track positions are available. But currently only 230 Heisenberg fellows are selected each year and the Fiebiger Program also supports relatively few people, and only in the wealthier states at that. According to Hubert Markl, president of the DFG, if the situation is not improved soon, it will have a "fatally discouraging effect" on young researchers in West Germany during the 1990 s and beyond.

Steven Dickman

\section{World population will soon reach five thousand million}

\section{London}

THE world's population will shortly reach 5,000 million, according to the United Nations Fund for Population Activities (UNFPA). Every minute it grows by 150 people, every day by 220,$000 ; 90$ per cent of this growth is in developing countries.

An increase in growth rates started in the eighteenth century and reached its peak in 1970. According to the United Nations, the growth rate is now declining, and will probably reach zero again in a

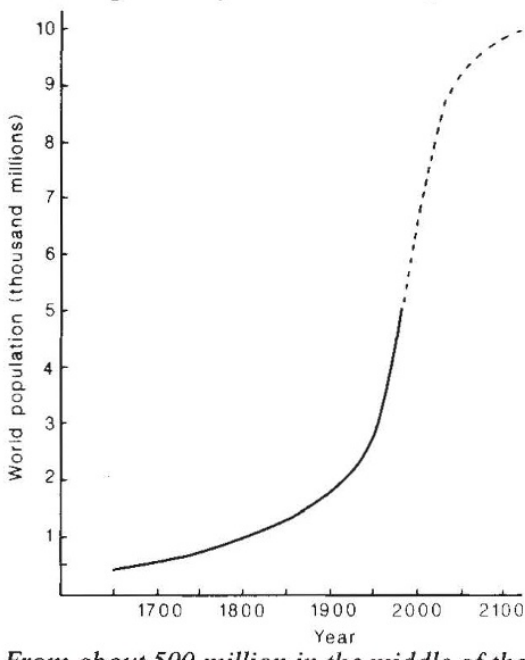

From about 500 million in the middle of the seventeenth century, the world population has risen to 1,000 million in the early nine teenth century and to 5,000 million in 1987. The assumptions made in the UN report suggest a population of 6,000 million in 1999.

century from now, when the world population is expected to stabilize at about 10,000 million.

"Developing countries are now undertaking family planning", said Dr Nafis Sadik, UNFPA executive director. "The ten countries with the largest populations are launching control programmes in a very active way. Even the countries of sub-Sahara Africa, which were never interested in population control before, have now adopted programmes for family planning. As a result, population growth levels will come down dramatically."

The declining growth rate for the developed countries has brought some sharp contrasts. Europe, including the Soviet Union, passed the half billion mark ( 500 million) before 1950; Africa attained it only in 1982. But Africa is expected to reach 1,000 million some time between 2005 and 2010; Europe will probably never reach it.

Forty per cent of the world's population now lives in urban areas; most of the world's largest cities are now in the developing regions.

In theory, according to the UNFPA, there is enough food for everyone, but its report quotes World Bank estimates that about one in six people worldwide do not eat sufficient calories for an active working life. In Africa, food production is up 20 per cent over the last decade, but per capita food production has fallen 11 per cent.

The State of the World Population report examines, and rejects, various arguments in favour of increased population growth. Sheer numbers of people, it concludes, do not contribute to economic development by increasing the potential for innovation. High fertility rates can gobble up many of the fruits of economic expansion, Sadik said, comparing Brazil to Japan.

The report also counters the idea that population growth does not affect the balance between humans and nature, pointing to deforestation and species extinction.
Kathy Johnston 